\title{
Whose forests, whose voices? Mining and com- munity-based nature conservation in southeastern Madagascar
}

\author{
Antonie Kraemer
}

\begin{abstract}
This paper explores local experiences of private-sector led community-based nature conservation near Fort Dauphin, southeastern Madagascar through the analysis of a conservation zone managed in partnership between the Rio Tinto mining corporation, local government and local communities. The article assesses how new forms of social inclusion and exclusion are generated through changes in land and resource access. The main findings are as follows: the community-based conservation programs near the Fort Dauphin mine were effective at mobilising local people but inadvertently favored certain members of society over others, as they involved a legitimization of resource access by established landowners. This granting of resource rights to some local users entailed the exclusion of already marginalised groups of landless migrants. Without land to cultivate, these migrants were more directly dependent on forest resources for their survival. Their livelihoods were based on selling forest products such as timber and handicrafts, in addition to working the land of others. This rendered their social status and ability to participate in development programs limited. Non-resident or recently settled resource users' voices had thereby not been adequately included in the conservation plans from the outset. Consequently, local landless migrants continued to break conservation rules, as they had no influence over the resource management process or realistic livelihoods alternatives. These circumstances reduced both the livelihood options of the poorest people near the mining site and the prospect of achieving equitable and sustainable natural resource management.
\end{abstract}

\section{RÉSUMÉ}

Nous proposons ici d'analyser des expériences locales intervenant lors du changement d'accès aux ressources naturelles dans le cadre d'un projet d'extraction minière et de conservation de la nature mené en partenariat entre une compagnie minière, le gouvernement local et les communautés riveraines d'un site minier près de Fort Dauphin, dans le sud-est de Madagascar. Les informations ont été recueillies lors d'une année de recherches ethnographiques financées par le conseil de Recherche Norvégien, aux alentours de la zone minière et de son site de conservation. Les changements d'accès à la terre et aux ressources naturelles induisent de nouveaux types d'inclusion et d'exclusion sociaux que nous avons étudiés ici.
School of Oriental and African Studies (SOAS)

Department of Anthropology and Sociology

University of London, U.K.

E-mail: a.kraemer@soas.ac.uk

Nous montrons que les programmes communautaires de conservation de la nature et de développement local établis auprès du site minier ont permis de mobiliser les villageois riverains, mais ont par mégarde créé des disparités entre certains membres de la société locale. Nous avons ainsi noté une augmentation de la différentiation sociale des propriétaires terriens traditionnels qui pouvaient revendiquer la légitimation des accès aux ressources naturelles. Cette légitimation se déroulait au cours d'une approche participative de cogestion environnementale, qui supposait un rang social élevé des participants mais aussi leur disponibilité pour pouvoir participer à ces programmes communautaires. Certains groupes extrêmement vulnérables comme les migrants sans terres ont ainsi été involontairement exclus à cause de cet octroi du droit d'accès aux ressources naturelles en faveur de certains groupes d'utilisateurs. En outre, sans terre à cultiver, ces migrants dépendaient encore davantage des ressources forestières pour assurer leur survie quotidienne. Leurs moyens de subsistance se limitaient à la vente de produits forestiers tels que le bois d'œuvre ou encore les roseaux pour I'artisanat. Une autre stratégie de survie importante pour les migrants sans terre était d'assurer la culture des terrains des propriétaires existants, permettant ainsi ces derniers à participer plus activement aux nouveaux programmes de gestion et développement local. En outre, les personnes les plus marginalisées résidaient souvent à l'extérieur des communes qui hébergeaient la zone de conservation et d'extraction minière, dans la mesure où il n'y avait plus de terre disponible dans ces communes. Le programme de conservation communautaire mené par la corporation minière était basé sur la mise en relation du droit aux ressources naturelles et de la résidence dans la commune hébergeant ces ressources. Or les personnes résidant hors de ces communes ou les personnes récemment installées et de statut social bas, étaient ainsi exclues dans la planification et la mise en œuvre de la gestion communautaire des ressources locales. Par conséquent, les migrants sans terre ne respectaient pas les lois de conservation communautaire, car ils n'ont pas pu influencer la procédure d'établissement des règles de gestion conjointes, ni accéder aux programmes d'activités génératrices de revenus alternatifs. Ces circonstances ont ainsi fait ressortir les limites de l'approche de conservation communautaire destinée à atténuer les impacts environnementaux du projet minier et à résoudre les conflits sociaux y afférents. 


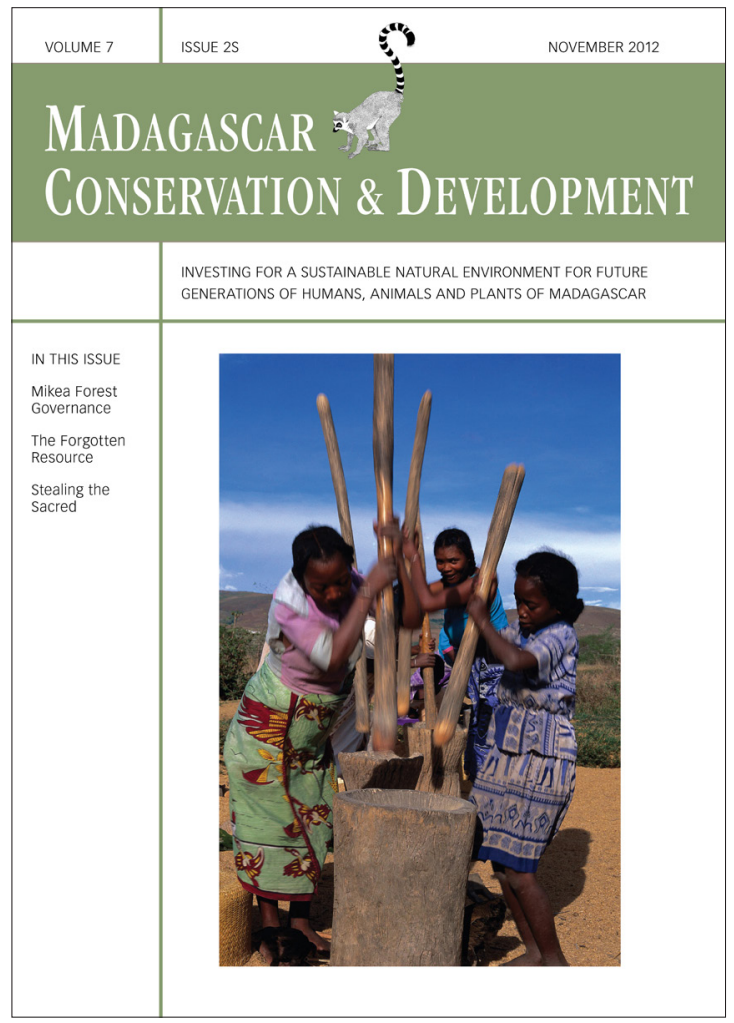

Madagascar Conservation \& Development is the journal of Indian Ocean e-Ink. It is produced under the responsibility of this institution. The views expressed in contributions to MCD are solely those of the authors and not those of the journal editors or the publisher.

All the Issues and articles are freely available at http://www.journalmcd.com

Contact Journal MCD

info@journalmcd.net for general inquiries regarding MCD funding@journalmcd.net to support the journal

Madagascar Conservation \& Development Institute and Museum of Anthropology University of Zurich

Winterthurerstrasse 190

$\mathrm{CH}-8057$ Zurich, Switzerland

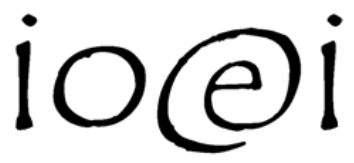

Indian Ocean e-Ink

Promoting African Publishing and Education www.ioeink.com

Missouri Botanical Garden (MBG)

Madagascar Research and Conservation Program BP 3391

Antananarivo, 101, Madagascar 


\section{INTRODUCTION}

The Rio Tinto ilmenite mine in southeastern Madagascar represents the first of two of the largest multinational mining ventures in Madagascar's history to date. It thereby sets a precedent for natural resource management in the context of an increasing national reliance on export-oriented extraction of non-renewable resources (Randrianja 2012). With socio-environmental impacts justified through ambitious mitigation programmes, the effects of these interventions require close independent monitoring and analysis. This is consistent with recent calls by social scientists (White et al. 2012) to account for the new mechanisms of inclusion and exclusion that are generated by the rapidly growing phenomenon of large-scale corporate land and resource access in Africa. In this context, a recent analysis argues that the Rio Tinto mine is an example of a global trend of 'inverting the impacts' of resource extraction, concealing the corporation's biodiversity destruction by shifting the blame onto local people (Seagle 2012).

Taking a more local perspective, this paper instead focuses on new forms of socio-environmental inclusion and exclusion caused by the changes in land and resource access near the mining zone. This may help to address some of the challenges with establishing effective social impact monitoring of the mining site. This issue is particularly urgent as the mining company has acknowledged that the establishment of a permanent and effective dialogue with local communities remains a challenge, including the establishment of a well functioning community feedback and complaint management mechanism (Rio Tinto QMM 2010). Furthermore, the socio-environmental impact assessment of the mining project's initial phase lists as the first obstacle to effective project monitoring the 'refusal of villagers to collaborate in certain activities' (QMM 2010) showing the importance of understanding local social dynamics.

The establishment of an effective community dialogue and social impact monitoring is a fundamental challenge, with the mining corporation itself pointing out that it operates in an impoverished region where 'the survival of the rural majority depends on the forest resources' (Rio Tinto QMM 2010). Concurrently, in a social impact assessment of the Mandena mining zone, the main issues brought up by local residents related to loss of food security and primary revenue sources due to the new restrictions in accessing natural resources (Hai-Tsinjo Consulting et al. 2008). In contrast, the mining project's latest socio-environmental impact assessment, under the key indicator of 'use of territory', concludes that changes in access to land and resources in the mining zone had 'no significant impact' because 'no complaints about conflicting usage' of the land had been registered (QMM 2010). Given the corporation's acknowledgement of a lack of a functioning complaints mechanism, an indicator based on the number of complaints received seems insufficient. This article therefore seeks to contribute to the analysis of local social impacts of the Rio Tinto mine, in order to widen the debate around these complex issues and improve the prospect for social impact monitoring and mitigation. Findings are based on a year's ethnographic research near the Mandena conservation and mining zone in southeastern Madagascar. All names of informants have been changed to protect their privacy.

\section{RAVAO'S STORY - SITTING STILL OR MOVING FORWARD?}

Along the road going north from Fort Dauphin town, where the forest towards the coast on the right hand side becomes dense, one passes by wooden signposts indicating the Mandena conservation zone. Behind it, hidden from view by the dense forest, lies the Rio Tinto ilmenite mining area. The dirt road, although in poor condition, is busy with large white $4 \times 4$ s and mini buses transporting mining, conservation and development staff. There are also clusters of simple raty (the leaf of Ravenala madagascariensis, traveller palm) roofed huts by the roadside. Inside one particular hut, there is an old tsihy (woven reed mat) covering the floor. In the light of the doorway, a small woman sits on the ground weaving a basket. Her fingers are rapidly moving in a complex pattern as she greets the stranger with a shy smile and a whispered "Mandrosoa! Come in!" Her name is Ravao, and she is a single mother tavaratsy (immigrant from the region's north). Her small hut was constructed with financial help from the nearby Catholic nuns on whom she depends to feed her daughter.

Ravao is weaving a basket made of long, sharp strips cut from vakoa (Pandanus concretus) leaves, which she hopes to sell by the road. She explains that she is not supposed to go into the forest to pick the leaves, due to the dina (community conservation agreement). However, if she follows these conservation rules, she will have no income at all. The mahampy (Lepironia mucronata, marsh based reeds) which are still allowed to be picked, and which Ravao also prefers to use as they make more popular handicrafts, are disappearing. Many have become off-limits as they are inside the guarded mining perimeter. The remainder, which are allowed to be picked, have all but disappeared. The marshlands they grow on are drying out and becoming invaded by the allochthonous kininy bonaky (Melaleuca viridiflora); Ravao is unaware of the cause.

Ravao explains that she wishes to obtain some land to cultivate crops. She laments that in spite of recent local development, "my life is not mivohatsy (progressing), with all the changes happening [in the mining zone], but mizetsy avao (it is only becoming more degraded). So now I am only sitting still, looking at the road, as even the mahampy reeds are gone."

There are new trial mahampy plantations established by the mining corporation in order to compensate for the loss of these reeds nearby. However, Ravao considers these areas as off-limits to immigrant women like herself. She does not have the social prestige to participate in the women's associations included in the new conservation management committee. Ravao complains that when there are work opportunities available, she and other mpivahiny (foreigners/ immigrants) will not benefit because, according to her experiences, all the opportunities are awarded to "those with family members on the inside".

However, Ravao is also hopeful: "I hope that kitefer [local name for the mining corporation] will let us pick the mahampy next year, if it grows well for them. Because I believe that it is possible to cultivate it - why not?" As such, Ravao is not against the mining project and the new environmental regimes it has brought. She does, however, feel unable to access these schemes due to her inferior social status as a landless migrant. she has no option but to rely on forest resources, which are now forbidden to exploit. 


\section{THE ANOSY REGION HISTORY - STRUGGLES OVER NATURAL RESOURCES}

In order to better understand why Ravao feels forced to break the conservation law and is unable to obtain a sustainable livelihood for herself and her daughter, it is helpful to briefly outline some of the regional history. The Anosy region of southeastern Madagascar has a long history of interaction with outsiders in struggles over land and resources. The region hosted the very first French settlement, establishing the Anosy capital of Fort Dauphin in the early $17^{\text {th }}$ century. Funded by the Compagnie Française de I'Orient, the first boat was sent from France in 1642 to export ebony wood from the region (de Flacourt 2007 [1661]), illustrating the importance of forest exploitation to the French colonial endeavour in southeastern Madagascar. These first colons encountered a highly hierarchical society of Araborigin rulers, middle classes and slaves (Rakotoarisoa 1998, de Flacourt 2007 [1661], Larson 2007), and conflicts over land and resources rapidly ensued. One of the first French Governors noted that 'there is no land in all the island that has no owner, and it is wrong to think that you can simply choose the land you want to cultivate. The masters and lords of the provinces [...] will not permit you to appropriate the smallest corner of their land' (de Flacourt 2007 [1661]), author's translation. Consequently, the first French instalment brought violent conflict and abruptly ended in 1674 with a massacre of the French settlers (Parker Pearson 1997).

Subsequent interactions with outsiders included traders seeking cattle, beeswax, sisal, mica and slaves (Parker Pearson 1997, Larson 2007, Campbell 2008). Slavery was officially abolished by the French in 1896, but continued in another guise for several decades under the name of engagisme, or plantation work contracts, with people departing from Anosy to work on the sugar plantations in La Réunion (Somda 2009). The region was also targeted by missionaries who aimed to convert and educate the population, and who took over substantial areas of land to establish their stations, with the region becoming a centre for the American-Norwegian Lutheran church, with competition from various Catholic denominations (Campbell 1988, Rakotoarisoa 1998, Somda 2009). The pre-colonial Merina invasion and garrison at Fort Dauphin in 1825 and resulting local resistance led to distress outward migration from the region (Rakotoarisoa 1998). Subsequently, ongoing cycles of famine in the neighboring Androy region as well as the need for finding salary-based work in order to pay taxes to the French colonial administration led to heavy flows of immigration (Middleton 1995, Campbell 2008). Following French colonization in 1896, French Governor-General Gallieni set out to build roads into the dense forests of Madagascar's eastern coast in order to facilitate the exporting of precious hardwoods such as rosewood and ebony (Gallieni 1908). French colonization of the Mascarene Islands (La Réunion and Mauritius) also created regular commercial links between these islands and Madagascar. Fort Dauphin was one of four strategic points for this trade, which concerned resources such as timber, rice, cattle and slaves (Deschamps 2012 [1976]). Local revolts against the new regime's land and resource capture, the suppression of tavy (swidden agriculture), as well as forced labor conscription and taxation culminated in a 1904 uprising which spread from Vangaindrano to Fort Dauphin (Somda 2009).

Due to the chaotic social changes of colonial days, including the imposition of land regulations benefiting large scale cultiva- tion and resource extraction ventures of foreigners, conflicts over land use and land rights play an important part in present day social tensions (Rakotoarisoa 1998). The region's land use and social dynamics have thereby been marked by conflicts over natural resources and land access between foreign colonisers and Malagasy and among Malagasy people themselves. This has fuelled ongoing flows of in- and out-migration. Moreover, a history of strict social hierarchy based on local social divisions between royalty, commoners and slaves has generated inequitable patterns of local land and resource distribution, which still persist (Somda 2009).

According to local oral history, people settled near the Mandena mining zone during the French colonial period. During this time, all men over 18 had to pay taxes and participate in corvée (forced) labor and people were forced to settle near principal roads in order to facilitate this (Campbell 1988). Local men and boys were sent to clear the forest to make way for the main road going north from Fort Dauphin town and to plant eucalyptus trees for the colon timber plantations. People also sought paid employment with colonial enterprises such as the nearby sisal processing plant and sawmill in order to pay taxes. After independence, these people stayed on to cultivate rice in the fertile, wet areas west of the present mining zone.

During the colonization period, most of the land in and near the mining zone was used for colonial timber and mining concessions, in addition to a large, state-run agricultural station and substantial Catholic church grounds. Mandena forest has itself been the subject of botanical interest since the 1950s, when a forestry station was established. Botanists began collecting specimens as part of an effort to document the island's woody plants, with approximately 500 described taxa made over the following three decades, several of which were species new to science (Lowry II et al. 2008). The current Mandena mining site was originally established as a nature reserve (station de reboisement, the least strict of three colonial forest reserve classifications) as two separate parcels of land in 1943 and 1955 during the French colonial government (Parcel 1 under the Arrêté de mise en réserve $\mathrm{N}^{\circ} 485$ of 19/05/43 and Parcel 2 under the Arrêté $\mathrm{N}^{\circ} 160-\mathrm{F} 3 / \mathrm{BOM}$ of $\left.23 / 12 / 55\right)$. The Malagasy state has maintained these classifications (Ministère de I'Intérieur et de la Réforme Administrative and Province autonome de Toliara 2001).

The colonial and Malagasy state had thereby managed forest regulation and introduced permit-based logging access for nearly half a century before the mining project began. However, according to local government officials, as state financial capacity dwindled during the economic austerity measures of the 1980s, enforcement of governmental resource management became non-existent. Local people accessed the forest for private use, in the context of a lack of clarity of both state and traditional management rules. The mining company's access to the Mandena forest for prospecting in the 1980s, including for building access roads, entailed a further disruption of resource management rules (Rakotoarisoa 1998, Ingram and Dawson 2006).

As we have seen, local land access and resource management have been shaped by a history of changes in user rights and regulations from pre-colonial times to the present. This included a lack of both state capacity and local community power in local resource management. Conservation and development challenges resulting from the mining corporation's 
land access must therefore be understood in the context of this complex history.

\section{PRESENT DAY - MINING AND CONSERVATION}

Fort Dauphin has recently experienced a radical shift from isolated and impoverished backwater to a showcase of Rio Tinto's corporate socio-environmental responsibility policies (World Bank 2005, Sarrasin 2006, Harbinson 2007). After initial exploration started in the late 1980s, Tinto subsidiary QIT Madagascar Minerals (QMM) secured an environmental permit to extract ilmenite from the littoral sands in Mandena in 2001. The first shipment in May 2009 marked the beginning of mining, projected to last for 25 years (QMM 2008). During the 20-year preparatory period, multiple socio-environmental studies, impact assessments and consultations were undertaken in response to political and environmental concerns. A special law introduced in the Malagasy parliament officially established the mining surface area of 2,100 hectares in the Mandena zone, the first of a projected total of 6,000 hectares, with the sites of St. Luce to the north and Petriky to the south of the Mandena zone still to be mined (QMM 2008).

The high profile mining project has led to multiple studies about the region's biodiversity and development challenges (e.g., Ganzhorn et al. 2007, Harbinson 2007, Lowry II et al. 2008, ALT and Panos 2009). Some studies have focused on mining-related changes in land and natural resource access (Mulligan 1999, Sarrasin 2006, Harbinson 2007, ALT and Panos 2009) and others on challenges of local governance and transparency (Smith et al. 2012). The causes behind deforestation of the littoral forests in the mining zones have also been debated, including multiple studies on the adverse impacts of local people's resource use (Tecsult International 2005, Rarivoson 2007, Vincelette et al. 2007). Others have highlighted exogenous factors for local deforestation, including climate-related causes such as temperature change and cyclones (Ingram et al. 2005, Virah-Sawmy 2009). A key non-local cause contributing to deforestation is mining-related infrastructure development (Ingram and Dawson 2006, Dawson and Ingram 2008, Watson et al. 2010, seagle 2012).

The stakes involved in this debate have led to the mining corporation setting out an ambitious community-based biodiversity conservation program, in order to convincingly demonstrate its global environmental policy of having a 'net positive impact' on biodiversity and society (Rio Tinto 2004, 2008). In response to concerns over its environmental impact, the mining corporation has set aside about $10 \%$ of the mining zone for conservation purposes (Rarivoson 2007, Vincelette et al. 2007). In the Mandena mining zone, 230 hectares were set aside in 2002 based on a tripartite agreement between the regional forest and water administration (CIREEF), the two host communes of Ampasy Nahampoa and Mandromodromotsy and QMM (Rarivoson 2007).

As outlined, the mining project and its socio-environmental program are a recent manifestation of the region's long history of struggles over access to land and natural resources. This history of rapidly shifting, unclear land tenure and resource access and ongoing flows of migration is important to bear in mind when seeking to analyze the mining project's social impacts and local people's related concerns and strategies.

\section{THE MINING ZONE - CONFLICTS OVER NATURAL RESOURCES}

This section seeks to highlight the differentiated dependence on forest resources among local communities near the Mandena mining zone. Such local, social diversity appears to have been neglected in other studies of local resource use, which tend to account for local people in terms of their impact on local biodiversity. However, it is an important aspect in understanding why the socio-environmental mitigation programs might inadvertently favor some groups of local people over others, with negative consequences for conservation, development and local livelihoods. A key paradox demonstrated in the present study is that the people who are most dependent on forest resources are precisely those who fail to qualify as the deserving 'local community' and are therefore less able to participate in the environmental community co-management programs.

A study by Ingram et al. (2005) demonstrated the important ecological services that the Mandena mining zone forest provides to local communities. Up to $84 \%$ of the standing trees in the littoral forests are utilitarian and provide an important resource for local livelihoods (Ingram et al. 2005). The tree species identified were primarily used for energy provision, construction materials, handicrafts, medicine, spiritual purposes such as ancestral blessings and funerals, food and oil. However, the study does not provide a nuanced analysis of local people in terms of their differentiated dependence on forest resources.

Issues of land and natural resource access represent important elements in the daily life, livelihoods strategies and patterns of social differentiation among local people. In this context, the importance of an entrenched and unspoken social hierarchy, as described in Somda (2009), is confirmed in a 2008 impact assessment of the Mandena mining project. The report identified as a primary obstacle to local development the low consideration of the opinions and rights of 'certain categories of the population' (Hai-Tsinjo Consulting et al. 2008). The poorest households are shown to be landless people dependent on forest resources for their daily survival.

During a year's ethnographic fieldwork conducted near the Mandena zone in 2008-2009, it was found that local land use and dependency on forest products differed according to existing access to cultivable land. Importantly, people who most depend on forest resources, such as the woman Ravao, are among the poorest of the local population. These people are often migrants who arrived over the last two decades due to poverty and hunger in their regions of origin. They are less able to qualify as participating members of the 'local community' invited to be involved in the corporation's socio-environmental mitigation programs. The reasons for this are twofold. Firstly, poorer migrants have less time available to participate in community programs as most days are spent gathering forest products or toiling others' land. Secondly, they lack local social networks and prestige, which are linked to traditional land ownership or permanent burial tombs in the commune. A major and ongoing problem is that of determining land rights of recently installed occupants. The mining corporation's environmental team experienced land access disputes when establishing the administrative body of the new mining and conservation zone (QMM 2008). Some occupants, who represented a combination of recently arrived migrants and extra-local land users based 
in Fort Dauphin town, were considered legitimate neither by existing, 'traditional' users nor by the administrative body. The corporation's environmental program thereby inadvertently participated in formalizing land and resource access rights to some groups of resource users to the exclusion of others. This further fueled local conflict over land and resources. A brief analysis of the socio-economic situation near the mining and conservation zone may serve to illustrate this point.

The Mandena mining zone, the first of three intended locations for ilmenite extraction, is situated within the two rural communes (municipalities) of Ampasy Nahampoa and Mandromodromotsy. This section focuses on the inhabitants of Ampasy Nahampoa commune living on the periphery of the Mandena mining site. According to the commune's 2003 Plan Communal de Développement, the commune covers an area of $87 \mathrm{~km}^{2}$ and officially has a population of approximately 4,000 people living in three fokontany (lowest government circumscription). However, many migrants have not been registered with their fokontany, therefore actual population figures are likely to be considerably higher (Province autonome de Toliary 2003). Indeed, a second government report cites a population numbering 7,200, showing the difficulty in establishing a realistic population estimate and thereby of monitoring social change in a commune characterised by ongoing migration (Primature and SIRSA 2006). Near the Mandena mining zone, the 2008 social impact baseline study for the mining project identified chronic food insecurity, lack of arable land to improve food production and dependency on local forest resources as key concerns for the $80 \%$ of local households which were considered to be very poor (Hai-Tsinjo Consulting et al. 2008).

The commune's average plot of arable land is a modest 1.5 hectares per family, of which cassava is the most common crop, followed by horaky (irrigated field) rice (Province autonome de Toliary 2003). In the less productive season (October-March), the staple food is cassava and rice becomes a purchased luxury commodity. There is constant risk of starvation in this region and occasionally, people are forced to eat via (Tiphonodorum lindleyanum, a water-based plant with semi-edible seeds and roots) and ovy ala (Dioscorea alata, wild yam). Less than $5 \%$ of inhabitants have certified land ownerships and less than half the population own a single cow, considered a buffer of household savings (Primature and SIRSA 2006). The lack of formal land tenure is characteristic of all of rural Madagascar and has facilitated the Rio Tinto mining corporation's land access as part of a wave of foreign large scale land acquisitions over the last decade (Andrianirina-Ratsialonana et al. 2011, Rakotondrainibe and TANY 2011).

The lack of legally recognized rights to land and natural resources on which local people depend is a fundamental social problem generating insecurity, poverty and food shortages. Of the commune's total land cover, $7 \%$ is used for food production, a very modest proportion of the commune's potential cultivable surface area (Province autonome de Toliary 2003, Primature and SIRSA 2006). As previously mentioned, this is due to large areas of productive land that remain titled to colonial-era foreign settlers, as is the case in many other parts of Madagascar (Rakotondrainibe and TANY 2011). In addition to the Mandena forest reserve converted to a mining and conservation zone, much of the land consists of eucalyptus forest plantations owned by the descendants of colonial landlords, private tourist reserves, and Catholic church land, rendering it unavailable to local farmers (oral communications with local residents).

The commune's population originates from many different parts of Madagascar, resulting in unequal land access and resource use rights. Most of the locally acknowledged land owners who were interviewed consider themselves Tanosy ('of Anosy') - people originating from the $18^{\text {th }}$ century Tanosy royal capital of Fanjahira in Ifarantsa commune to the west of the mining zone. The preferred male livelihood involves owning rice fields for practicing wet rice cultivation and raising cattle. Tanosy women typically generate independent income by gathering reeds and other weaving materials in the Mandena forest marshlands in order to make handicrafts such as mats, containers, baskets and hats. Household monetary income is generally not pooled and land and cattle belong to the men, making women an economically vulnerable group regardless of social status.

Local migrants are mostly Tavaratsy (from the northern part of the Anosy Region) or Tesaka (people originating from the Vangaindrano area to the north of Anosy). They reported that they had migrated from areas affected by famine and economic uncertainty and settled near Fort Dauphin town in order to improve their earning prospects. Another important social group accessing natural resources in the commune are Tandroy, people from the Androy Region to the southwest of Anosy. Older Tandroy settlers reported how their parents had fled from the kere (famine) in the 1930s (Middleton 1999) and found employment with French sawmilling and sisal industries established in and near Fort Dauphin town.

There is a division in land and resource use between long-established residents and more recently arrived migrants, with important consequences for both conservation and social development. People considering themselves to be 'true' Tanosy report that they do not access the forest to harvest wood for commercial gain such as for timber or making charcoal. Such activities are considered to be associated with low social status: an indication that one does not own rice fields nor live near one's ancestral tombs. These are key elements of identity in most parts of Madagascar (Bloch 1971). Land ownership and ancestral tombs also represent social capital in a hierarchical society where unclear familial origins and a lack of land ownership may raise suspicion as to criminal intentions, slave origins, witchcraft or bad luck (Evers 2002).

In contrast to the Tanosy, the Tavaratsy and Tesaka migrants living near the mining zone generally have little access to cultivable land, as it is already owned. Instead, men and women frequently work as dabok'andro (salaried day workers or sometimes sharecroppers) on landowners' rice and manioc-fields to the west of the mining zone. Migrant men who have settled near the littoral forest of Mandena generally rely on gathering and selling forest products for timber construction and charcoal making. These products have become increasingly profitable due to the growing construction market in the booming mining town of Fort Dauphin. Migrant women such as Ravao rely on picking forest products such as reeds for weaving in the Mandena forest zone and selling woven handicrafts, as well as gathering firewood, fruit and other products they can sell along the roadside. 
As demonstrated, those most dependent on forest resources are among the commune's poorest. These people are often migrants who have arrived over the last two decades and therefore are less able to qualify as members of the 'local community' who could participate in the corporation's socioenvironmental mitigation programs.

\section{THE MANDENA DINA - INTENTIONS AND REALITIES OF RESOURCE CO-MANAGEMENT}

The socio-environmental programs near the mining zone favored landowning residents over forest-dependent migrants. This resulted in the corporation's intentions of mitigating negative mining impacts through participative nature conservation and poverty reduction programmes being less effective than they could have been had their scope been more inclusive. Furthermore, local conflicts over land and resource access increased as the corporation's political and economic power was deployed in favor of one group.

The GELOSE (GEstion LOcale SEcurisée) legislation passed in 1996 (law 96-025) facilitated the transfer of natural resource management from national government to local communities. This was achieved through contracts between rural communities, the central government and local communes, giving 'exclusive rights' - although not ownership - to resources to the community that signed the contract (Kull 2002, 2004, Bertrand and Ratsimbarison 2004, Pollini and Lassoie 2011). Such contracts also included drawing up dina, 'local common law regulations' (Bertrand and Ratsimbarison 2004) regulating access to, and use of, the natural resources.

Such a dina has been used by QMM to justify corporate land access. In various publications, QMM states that local acceptance of the mining project had been ensured through a 'traditional legal agreement', and that as dina 'are anchored in custom and tradition, they render legal agreements culturally acceptable' (QMM 2007, QMM 2012). The Mandena dina follows this legal basis and specifies the boundaries of the mining and conservation zone, as well as user fee regulations for those parts of the area still accessible to local people.

It is worthwhile to briefly recall the recent reinvention of dina in Madagascar. These legal agreements have taken on particular significance in Madagascar since the 1990s, when conservation and development actors first used them as an expression of local culture. This was in response to demand for more participatory approaches in conservation programs, which had previously been managed in a top-down manner that had proven ineffective and inequitable (Kull 2002). However, as Pollini and Lassoie (2011) and Corson (2011) contend, the GELOSE approach, which sets the legal framework for such dina, has largely failed to fulfil its assurances of genuine local participation and of transferring land ownership rights. Rather, it has entailed a top-down creation of new local institutions imposing an external conservation agenda. This has resulted in appropriation of resources by local elites who tend to dominate in the new institutions. Primarily, these are the literate elite familiar with the language of conservation, who understand and match the objectives and rationale of conservation agencies. Similarly, Bérard (2009) demonstrates how the deployment of dina as an expression of local culture has been more discourse than a representation of reality, and has often failed to gain legitimacy among local farmers.
The Mandena conservation zone dina was implemented via a management committee, or Comité de GEstion (COGE). The COGE was intended to be the representative body of the local community residing within the two communes that host the mining project, in partnership with local government and the mining corporation (Rarivoson 2007). The dina stipulates that the local community consists of residents in the two communes.

However, many migrant users were not considered to be part of the local community listed in the COGE. Most were based outside the two mining host communes, where, as we have seen, little land was available for settlement. Some migrants were also living in poorer areas of Fort Dauphin town itself, walking the few kilometres to the Mandena forest on a daily basis.

As the mining corporation's environmental team identifies, the process of establishing the dina involves distinguishing 'the groups with pre-existing rights from those who seek access to rights, and to know what these rights are' (Rarivoson 2007). Those considered as having pre-existing rights, who therefore also qualified as members of the COGE management team, were represented by members of 'the user groups, formal village associations (e.g., associations of women, loggers, producers of different forest products and crafts), the communal development boards in charge of preparing the development plans, and the representatives of the elders and the lineage chiefs' (Rarivoson 2007). This process reflects Pollini's (2007) critique of the community-led resource management law of Madagascar, where 'community' is reduced to 'association' and traditional hierarchies, usually local male landowners, thereby excluding the most marginalised resource users.

The establishment of the Mandena dina involved a formalization of user rights to access natural resources based on residency in one of the two host communes. These rights were also based on membership in existing 'community associations' and a high standing position within the existing social hierarchy, which depended on the authority of local lonkay (lineage heads) and toteny (community spokespeople). The two latter groups usually consist of older men from dominant, land-owning lineages (Rakotoarisoa 1998, Rarivoson 2007, Somda 2009). As such, the corporate socio-environmental team's criteria for identifying rightful resource users favored existing landowners and elites who were less dependent on forest resources than other users.

The COGE (management committee) was the forum for establishing resource use rules and implementing these rules through community-run forest brigades. The committee was financed by the mining corporation and the two participating communes as well as through resource user fees. Ultimately, this management system was to become financially self-sufficient, based on revenue-generation from forest user fees and via projects such as eco-tourism, a plant nursery, research, honey production, and vegetable gardening (Rarivoson 2007). In order to achieve this, COGE members received training on 'upgrading' the conservation site in order to 'maximize revenues' (Rarivoson 2007). A key aspect of the corporation's socio-environmental programs included establishing alternative income generation channels based on local entrepreneurship via the 'Mandena Integrated Development Programme'. This program was intended to compensate for loss of land and natural resource access. However, as previously outlined, those most negatively impacted by restricted access to natural resources, the migrant 
population, were less able to participate in these programs as they were not members of the recognised, official 'community'.

In theory, the Mandena dina envisaged that the mining corporation would transfer land access rights and establish compensation programs and management responsibilities for parts of its land concession to local communities. In reality, however, the transfer of access rights was limited. The relevant law requires that GELOSE contracts and resource management dina conform with existing legislation and rules (Kull 2002) including the Malagasy state's legal ownership of all land not individually titled (Sandron 2008). This ownership in practice ensures the state's ongoing ability to grant exclusive land and resource rights to international extractive industries in spite of the GELOSE legislation's intention of securing local traditional land ownership and resource use.

As such, in spite of the corporation's stated community co-management policy via the Mandena dina, the mining corporation ultimately still had official rights to the 2,100 hectares of land in the Mandena mining and conservation zone as set out in the 2001 mining permit. Indeed, in most GELOSE-based resource management transfers, the potential 'relative land tenure securization' in favour of local people is not implemented because it is costly, can reveal difficult land tenure conflicts and is not perceived as important by the implementers of management transfers, such as local state officials and conservation NGO personnel (Pollini and Lassoie 2011).

This was similarly the case for the Mandena mining zone, where land disputes between local land and resource users and the mining corporation were ongoing despite the dina. Such conflicts, which included roadblocks and local demonstrations, led to the corporation having to acknowledge the usufruct rights of non-resident land users, thereby questioning the basis for the community management structure. In an explanatory note issued on 9 February 2009 after ongoing roadblocks by local resource users had ended due to interventions by the army, the corporation stated that the mining zone's land when not being mined would be available for use by migrant users (QMM 2009). They would also be included in the Mandena dina. However, according to regional government officials, these new resource users had no right to build houses or register as theirs the land they were cultivating. Therefore, the Mandena dina shifted resource management responsibilities onto local people without a corresponding shift in land ownership rights. A sample of local stakeholder experiences of this new resource governance model, analyzed in terms of new forms of social inclusion and exclusion, are discussed next.

\section{LAND AND RESOURCE PRIVATIZATION - CASES OF INCLUSION AND EXCLUSION}

Participatory conservation programs engender a legalization of who is included in the community and who deserves to represent it. It can officialize certain people's land and natural resource access over others'. This may lead to unintended social changes when locally dominant actors are better placed to benefit as program participants relative to others (Kull 2002, Pollini 2007, Corson 2011). Conversely, this excludes the most marginalised local people, such as Ravao.

The following are brief descriptions of the people who came to represent the local community through membership of the Mandena conservation zone's COGE (management committee).
'Paoly', a prominent member of the COGE, was a young and dynamic man. He was literate and at ease speaking with the many vazaha (foreigners) who had arrived in connection with the mining, conservation and development projects near the Mandena zone. I was told by other COGE members that Paoly had been selected to have an important position because he was of the dominant lineage of the hamlet considered traditional owners of Mandena forest. As such, efforts had been made to respect local traditions when setting up the conservation zone.

Paoly's father was a lonaky (head of lineage) who allegedly owned 50 cattle, making him a considerably wealthy man within the region. He lived however in a simple, small traditional leafroofed house similar to other huts in the area. Flaunting wealth and ownership is poorly regarded and would engender jealousy and supposed ill fortune. As a result, an apparently homogenous hamlet of huts with a population subjected to the same conditions of poverty may in fact contain major disparities in wealth between households.

Paoly was an ideal project participant. He was educated and owned cattle and rice fields, which were tended by salaried day-workers. Paoly therefore had enough free time to participate in the many COGE-related meetings. He explained that the new resource management system was a positive initiative for the local community. Employing official conservation terminology with ease, Paoly stated frankly that "the COGE is for us, the landowners, to better manage the forest and generate income for the fokonolo (community). There are also mpiavy (derogatory word for immigrants) nearby who use the forest [...]. They are not part of the COGE, though we are considering inviting them, as their absence is creating problems, since they also use the forest. But the mpiavy are not trustworthy, as we do not know their origins [this phrasing implies that they are suspected by Paoly to be descendants of slaves]. They are sometimes exiled people, such as thieves and mpamosavy (witches). And they are the ones who mandika dina (break the conservation law)." There were indeed problems with the illicit cutting of timber to be sold in Fort Dauphin town, with certain people not paying the user fees in the limited access zone, or with charcoal making.

Landowners such as Paoly did not have to do such work, which in addition to being physically hard is considered to be socially degrading work of people with no cultivable land. As recognised 'community representatives' with the mining corporation's logo on their COGE uniforms, people such as Paoly were instead able to consolidate their position as rightful land and resource owners.

As part of field research in the region, the researcher accompanied some of the forest patrols near the Mandena forest user zone. This was the area outside of the Mandena conservation zone, but within the mining zone, where according to the dina, people were able to harvest certain forest products. User fees were gathered almost exclusively from migrants who accessed the forest daily either from nearby hamlets or from the poorer quarters of Fort Dauphin town.

Two COGE forest brigade members explained that they were hired because they were considered tena tompontany (real land-owners) of nearby Mangaiky village. One woman of the forest brigade declared, "now that the vazaha [foreigners] are here, we must follow their rules, we are forced to, as they are vazaha. We therefore set up a fikambana [community association] to fight against charcoal makers, especially people from 
Amaroamalo [nearby hamlet of recently arrived migrants], who came to burn the trees here. There were at least 42 people who came here to make charcoal and burn the forest. They even burnt the trees by the tombs, and they also chopped down trees for selling timber. In contrast, people's livelihoods here, the real landowners, is cultivating rice and picking mahampy [reeds for weaving]. However, in the end kitefer [the mining company] listened to our complaints, and helped us get rid of them, by asking for help from the gendarmes."

The above statements demonstrate the struggles that were developing over increasingly scarce land and natural resources between existing landowners and migrants seeking immediate financial rewards. Such tensions made local conflict resolution based on dina difficult to achieve, with landowners instead getting assistance from government law enforcement, via the mining corporation. Issues of insufficient land and resource access could not be addressed through a community-based mechanism such as the Mandena dina, which was based on a presumed unitary group of self-organizing local users with unchanging land and resource needs. The dina thereby failed to successfully address the tensions generated by expanding local land and resource needs by impoverished migrants.

Forest brigade members' statements also illustrate how to local people, the mining corporation represented powerful outsiders, conceived of simply as vazaha, and was frequently conflated with the state. This perception appeared to be confirmed by the provision of local police in support of the corporation's conservation program. As a result, while in theory the dina was an instrument of community-based management, in practice it was not so. Conservation rules were implemented with the support of state law enforcement rather than community sanctions. Indeed, many forest brigade members reported that the dina itself was unenforceable due to the social tension such official community sanctioning would create. This included fear of retaliation through witchcraft and poisoning targeted at forest brigade members if they publicly accused individuals of contravening the dina.

Environmental issues were not at the forefront of the Mandena conservation program at a local level. Rather, it was conceived of in terms of relationships between local people and outside powers, whether foreign or the Malagasy state, similarly to the situation encountered by Keller (2009) near the Masoala National Park. Groups strategically sought to align themselves with these powers in order to gain benefits and power, including by becoming members of the COGE and forest brigade.

Local social categories are, however, not fixed, and some migrants did manage to become landowners. 'Angeline' was one of the COGE's female members of Tandroy origin who had grown up next to the Mandena mining and conservation zone. Her family had migrated there in the 1940s due to the kere (famine) in the Androy. The family established themselves by the main road on unclaimed land and planted lychee trees as a cash crop, which also served to indicate their land ownership. Angeline set up a women's association for needlework and other income-generating projects in the 1980s, supported by the local order of nuns. As an association president, she qualified for COGE membership, as the mining corporation had made use of existing community associations in order to facilitate the establishment of the Mandena dina (Rarivoson 2007). Individuals like Angeline, who managed to establish themselves as local residents with social capital and networks, were thus empowered by the dina.

In spite of immigrant origins, Angeline's family ascended to becoming tompontany and recognised community members by claiming land. This reflects the conflict between paper-based, legal notions of stable communities of 'users' with fixed rights, on the one hand, and the fluid realities of coping with rural poverty through migration in Madagascar, on the other (e.g., Comaroff and Comaroff 1987, Ferguson 1999, Evers 2002, Keller 2008), as elsewhere in Africa (Kopytoff 1987). Given its history, these dynamics are particularly pertinent to the Anosy region, where ongoing land privatization is causing further social differentiation between existing landowners and the many recently arrived migrants. As the latter are not able to access new land to clear for farming, they instead depend on accessing forest and other natural resources for their survival.

Local landowners also made use of the forest and therefore had to abide by dina regulations, including paying user fees. The forest was deemed particularly valuable for keeping cattle hidden from thieves, although that was no longer permitted. Landowners further made use of the forest for private housing materials, reeds and medicinal plants. When seeking forest access, these groups of people, usually interrelated, were able to negotiate the dina to their advantage, although many lamented the loss of access for grazing cattle.

A Tanosy landowner and lineage head was able to benefit from the dina, because according to him, "the COGE's management now, it is nothing compared to the Ministry's management! It is tena maiva [much lighter], at least that is what I think. In the past, if you were caught by the Ministry, they took your wood that you had cut, and forced you to plant new trees, if not they took you to the police and to jail. Now, with the COGE, we can mifagnanatsy [arrange things between ourselves], because we are all from the same area." Clearly, for the tompon-tany, the dina could be negotiated to one's advantage, and it entailed a welcome withdrawal of government monitoring of natural resources. Indeed, the institution did have local support, namely that of certain elites but not from the majority of the local community. As Pollini and Lassoie (2011) and Corson (2011) argue, this is a common weakness of the GELOSE legal framework in Madagascar.

'Rajean', a landless immigrant from Manantenina commune 150 $\mathrm{km}$ to the north of the mining zone worked as a land guardian and sharecropper for the above-cited landowner. Rajean revealed that he could no longer enter the Mandena forest to obtain construction wood due to the forest brigade patrols and user fees. Rajean rarely had adequate funds to spend on the fees, as his salary was paid in crops. He obtained cash revenue from selling forest products. Rajean was afraid to enter the zone to fish in the lakes, which had been permitted previously, because he had been accused by forest guards for damaging wood with his fish-gutting knife.

The exclusion of Rajean from forest access prevented their household from obtaining fish, an important source of nutrition for his family. Additionally, without income from selling construction wood, Rajean could not afford to adequately feed his four children, who suffered from malnutrition. Rajean admitted, however, that if he received orders from town to collect wood for construction then he would covertly steal the order of wood. His main source of monetary revenue had 
been criminalized. Concurrently, as a landowner's guard and sharecropper, Rajean did not possess either the social status or time to partake in the alternative livelihoods projects established by the mining corporation. Had he been able to, Rajean would have opted to plant crops on his own land. He instead hoped to save enough money to return to his home village in Manantenina. This commune often generates outmigration due to chronic hunger. However, to Rajean, his home commune was becoming more attractive than the Fort Dauphin area despite mining-related development. In spite of the stated intentions of corporate responsibility and community conservation programs, the above stories show how some of the mining zone's most marginalised people bore the brunt of land and resource loss through mining and conservation.

\section{CONCLUSION}

This article has analyzed social effects of community-based forest management in the context of mining-led conservation and development efforts. It is apparent that new local mechanisms of inclusion and exclusion have appeared as certain groups have been better able to position themselves as participants in the new, community-based management structures. These groups have had existing resource access rights confirmed by being recognized as rightful local landowners and resource users in the new nature management regimes, as well as by influencing the enforcement of forest access rules. This dominance by one group led to more marginalised people being even more excluded. These people were mostly landless migrants and therefore particularly dependent on forest resources for their modest livelihood.

Consequently, the people who represented the community in negotiations about forest management were not those who most depended on forest resources for their survival. This had negative consequences both for conservation and development objectives. Long-term residents in the mining zone communes whose livelihoods were based on wet rice cultivation outside the forest had employees to work their land and were better placed to access the new, participatory conservation schemes.

The mining corporation's support of one group, despite intending to allow for local participation in conservation and development, thereby inadvertently furthered local resource conflicts. New land and resource access regimes tended to exclude the poorest component of the population. Ultimately, the conservation agreement was supported by governmental law enforcement rather than community-based solutions. In a context of conflicts over increasingly scarce land and natural resources near the mining zone, the social tensions generated by peer sanctioning were too high to allow for effective automonitoring by community members.

Finally, the community management model failed to address the fundamental issue of marginalised people's lack of access to arable land. In addition to the mining and conservation zone, other large areas of potentially cultivable land were still titled to colonial era owners and used for eucalyptus plantations, private nature reserves and church grounds. With the mining corporation's alternative livelihoods programs being inaccessible to many local migrant people, they had no alternative but to keep accessing forest resources beyond what was permitted. Because the voices and concerns of the most marginalised, forest-dependent people were excluded from the start, they became more likely to break the conservation rules. Apart from furthering social inequity, this inevitably led to conservation objectives being compromised.

\section{ACKNOWLEDGMENTS}

The author would like to thank the research participants, in particular the people in and near Fort Dauphin and staff at the Rio Tinto/QMM socio-environmental team. Funding was provided by the Norwegian Research Council and the SOAS Fund for Fieldwork. Many thanks to the three anonymous reviewers and the editors for their invaluable corrections and suggestions. The author takes full responsibility for any errors and omissions.

\section{REFERENCES}

ALT and Panos 2009. Voices of Change: Oral Testimony of the Antanosy People. Andrew Lees Trust and Panos London. Available at <http://andrewleestrust.org/hepa.htm>

Andrianirina-Ratsialonana, R., Ramarojohn, L., Burnod, P. and Teyssier, A. 2011. After Daewoo? Current status and perspectives of large-scale land acquisition in Madagascar. International Land Coalition. Available at <http://www.landcoalition.org/sites/default/files/publication/905/ CIRAD_OF_Mada_ENG_web_16.03.11.pdf>

Bérard, M.-H. 2009. Légitimité des normes environnementales et complexité du droit: L'exemple de I'utilisation des DINA dans la gestion locale de la forêt à Madagascar (1996-2006). Unpubl. Ph.D. thesis, Université Laval, Québec.

Bertrand, A. and Ratsimbarison, R. 2004. Deforestation and fires: The example of Madagascar. In: Beyond Tropical Deforestation: From Tropica Deforestation to Forest Cover Dynamics and Forest Development. D. Babin (ed.), pp 79-88. UNESCO and CIRAD, Paris.

Bloch, M. 1971. Placing the Dead: Tombs, Ancestral Villages and Kinship Organization in Madagascar. Seminar Press, London and New York.

Campbell, G. 1988. Missionaries, fanompoana and the Menalamba revolt in late nineteenth century Madagascar. Journal of Southern African Studies 5, 1 : 54-73. (doi:10.1080/03057078808708191)

Campbell, G. 2008. An Economic History of Imperial Madagascar, 1750-1895: The Rise and Fall of an Island Empire. Cambridge University Press, New York.

Comaroff, J. L. and Comaroff, J. 1987. The madman and the migrant: Work and Labor in the Historical Consciousness of a South African People. American Ethnologist 14, 2: 191-209. (doi:10.1525/ ae.1987.14.2.02a00010)

Corson, C. 2011. From rhetoric to practice: How high-profile politics impeded community consultation in Madagascar's new protected areas. Society and Natural Resources: An International Journal 25, 4: 336-351. (doi:10.1 080/08941920.2011.565454)

Dawson, T. P. and Ingram, J.C. 2008. Sustainable livelihoods and forest resources in Madagascar: A multi-scale analysis using remote sensing. Environmental Sciences 5, 2: 129-143. (doi:10.1080/15693430801912188)

de Flacourt, É. 2007 [1661]. Histoire de la Grande Isle Madagascar. Nouvelle édition, annotée, augmentée et présentée par Claude Allibert. INALCO \& Karthala, Paris.

Deschamps, H. 2012 [1976]. Tradition and Change in Madagascar, 1790-1870. In: The Cambridge History of Africa: Volume 5: From c. 1790 to c. 1870, J. E. Flint (ed.). Cambridge University Press, Cambridge. (doi:10.1017/ CHOL9780521207010.013)

Evers, S. J. T. M. 2002. Constructing History, Culture and Inequality: The Betsileo in the Extreme Southern Highlands of Madagascar. Koninklijke Brill, Leiden, The Netherlands.

Ferguson, J. 1999. Expectations of Modernity: Myths and Meanings of Urban Life on the Zambian Copperbelt. University of California Press, Berkeley and Los Angeles, California.

Gallieni, J. S. 1908. Neuf ans à Madagascar. Librairie Hachette et Cie, Paris.

Ganzhorn, J. U., Goodman, S. M. and Vincelette, M. (eds.). 2007. Biodiversity, Ecology and Conservation of Littoral Ecosystems in Southeastern Madagascar, Tolagnaro (Fort Dauphin). Smithsonian Institution, Washington D.C. 
Hai-Tsinjo Consulting, CARE International, Association Action Socio-sanitaire and QMM 2008. Rapport sur l'étude des conditions de vie des ménages des communes environnant le site d'exploitation d'ilménite dans la zone Mandena.

Harbinson, R. 2007. Development Recast? A Review of the Impact of the Rio Tinto IImenite Mine in Southern Madagascar. Report for Friends of the Earth, UK. Available at <http://www.foe.co.uk/resource/reports/ development_recast.pdf $>$

Ingram, J. C., Whittaker, R. J. and Dawson, T. P. 2005. Tree structure and diversity in human-impacted littoral forests, Madagascar. Environmental Management 35, 6: 779-798. (doi:10.1007/s00267-004-0079-9)

Ingram, J. C. and Dawson, T. P. 2006. Forest Cover, Condition, and ecology in human-impacted forests, south-eastern Madagascar. Conservation and Society 4, 2: 194-230.

Keller, E. 2008. The banana plant and the moon: Conservation and the Malagasy ethos of life in Masoala, Madagascar. American Ethnologist 35, 4: 650-664. (doi:10.1111/j.1548-1425.2008.00103.x)

Keller, E. 2009. Who are they? Local understandings of NGO and state power in Masoala, Madagascar. Tantsa 14: 76-85.

Kopytoff, I. 1987. The internal African frontier - the making of African political culture. In: The African Frontier: The Reproduction of Traditional African Societies. I. Kopytoff (ed.), pp 3-84. Indiana University Press, Bloomington \& Indianapolis.

Kull, C. A. 2002. Empowering pyromaniacs in Madagascar: Ideology and legitimacy in community-based natural resource management. Development and Change 33, 1: 57-78. (doi:10.1111/1467-7660.00240)

Kull, C. A. 2004. Isle of Fire: The Political Ecology of Landscape Burning in Madagascar. The University of Chicago Press, Chicago.

Larson, P. M. 2007. Colonies lost: God, hunger, and conflict in Anosy (Madagascar) to 1674. Comparative Studies of South Asia, Africa and the Middle East 27, 2: 345-366. (doi:0.1215/1089201x-2007-010)

Lowry II, P. P., Randriatafika, F. and Rabenantoandro, J. 2008. Conservation status of vascular plant species from the QMM / Rio Tinto mining area at Mandena, Tolagnaro (Fort Dauphin) region, southeast Madagascar. Madagascar Conservation \& Development 3, 1: 55-63.

Middleton, K. 1995. Tombs, umbilical cords, and the syllable fo. In: Cultures of Madagascar: Ebb and Flow of Influences. S. Evers and M. Spindler (eds.), pp 223-235. IIAS, Leiden, The Netherlands.

Middleton, K. 1999. Who killed 'Malagasy cactus'? Science, environment and colonialism in southern Madagascar (1924-1930). Journal of Southern African Studies 25, 2: 215-248. (doi:10.1080/030570799108678)

Ministère de IIntérieur et de la Réforme Administrative and Province autonome de Toliara 2001. Données économiques et sociales, Region d'Anosy.

Mulligan, P. 1999. Greenwash or blueprint? Rio Tinto in Madagascar. DS Bulletin 30, 3: 50-56. (doi:10.1111/j.1759-5436.1999.mp30003007.x)

Parker Pearson, M. 1997. Close encounters of the worst kind: Malagasy resistance and colonial disasters in southern Madagascar. World Archaeology 28, 3: 393-417. (doi:10.1080/00438243.1997.9980355)

Pollini, J. 2007. Slash-and-burn cultivation and deforestation in the Malagasy rain forests: Representations and realities. Unpubl. Ph.D. thesis, Cornell University.

Primature \& SIRSA 2006. Atlas des données structurelles concernant la sécurité alimentaire dans la Région de l'Anosy - Madagascar. Atlas des données structurelles - Système d'Information Rurale et de Sécurité Alimentaire (SIRSA).

Province autonome de Toliary 2003. Plan Communal de Développement, Commune Rurale d'Ampasy Nahampoana. Province autonome de Toliary, sous-préfecture de Fort-Dauphin

QMM 2007. Community Relations strategy and plan. <http://production.investis.com/ qmm/siteware/pdfs/community-relations-plans.pdf> accessed 1 July 2012.

QMM 2008. Projet IIménite - Plan d'aménagement et de Gestion de Mandena (PAG) 2008-2009.

QMM 2009. Note d'Information: Résolution des différends sur l'utilisation des terrains dans le périmètre minier de Mandena (Ref : QMM/COM/0003/09, 6 février 2009).

QMM 2010. Exploitation des sables minéralisés de Fort-Dauphin: Bilan des suivis sociaux et environnementaux 2005-2009, Phase construction, Parties 7 à 12. Déposé par QIT Madagascar Minerals S.A. (QMM S.A.) auprès de I'Office National pour l'Environnement de Madagascar, mars 2010.
QMM 2012. The Dina <http://www.riotintomadagascar.com/english/sustainSocioDINA.asp> accessed 3 May 2012.

Rakotoarisoa, J. A. 1998. Mille ans d'occupation humaine dans le SudEst de Madagascar : Anosy, une île au milieu des terres. Éditions I'Harmattan, Paris.

Rakotondrainibe, M. and TANY 2011. Annexe à la pétition: Halte aux explusions des familles malgaches et à l'accaparement des terres à Madagascar. Available at <http://terresmalgaches.info/IMG/pdf/ ANNEXE_petition_Halte_aux_expulsions.pdf>

Randrianja, S. 2012. Love me tender - Transition vers où ? Madagascar Conservation \& Development 7, 1: 9-16. (doi:10.4314/mcd.v7i1.3)

Rarivoson, C. 2007. The Mandena dina, a potential tool at the local level for sustainable management of renewable atural resources. In: Biodiversity, Ecology and Conservation of Littoral Ecosystems In Southeastern Madagascar, Tolagnaro (Fort Dauphin). J. U. Ganzhorn, S. M. Goodman and M. Vincelette (eds.), pp 309-316. Smithsonian Institution, Washington D.C.

Rio Tinto 2004. Rio Tinto and Biodiversity: Achieving Results on the Ground. Available at <http://www.riotinto.com/documents/ ReportsPublications/RTBidoversitystrategyfinal.pdf>

Rio Tinto 2008. The Way We Work: Our Statement of Business Practice. Available at <http://www.riotinto.com/documents/The_way_we_ work.pdf>

Rio Tinto QMM 2010. Qit Madagascar Minerals SA Rapport de Developpement Durable 2010. Available at <http://www.riotintomadagascar.com/pdf/RDD_2010_FR.pdf>

Sandron, F. 2008. Population rurale et enjeux fonciers à Madagascar. CITE, Antananarivo \& Karthala, Paris.

Sarrasin, B. 2006. Économie politique du développement minier à Madagascar : I'analyse du projet QMM à Tolagnaro (Fort Dauphin). Vertigo - La revue en sciences de l'Environnement 7, 2: 1-14.

Seagle, C. 2012. Inverting the impacts: Mining, conservation and sustainability claims near the Rio Tinto/QMM ilmenite mine in Southeast Madagascar. Journal of Peasant Studies 39, 2: 447-477. (doi:10.1080/0 3066150.2012.671769)

Smith, S. M., Shepherd, D. D. and Dorward, P. T. 2012. Perspectives on community representation within the Extractive Industries Transparency Initiative: Experiences from south-east Madagascar. Resources Policy 37, 2: 241-250. (doi:10.1016/j.resourpol.2011.01.001)

Somda, D. 2009. Et le réel serait passé. Le secret de I'esclavage et I'imagination de la société (Anôsy, Sud de Madagascar). Unpubl. Ph.D. thesis, Université Paris X - Paris Ouest Nanterre la Défense, Paris.

Tecsult International 2005. Évaluation de l'impact environnemental et social du Projet Pôles Intégrés de Croissance Pôle de Croissance de FortDauphin: Cadre de gestion environnementale et sociale. Report submitted to the National Secretariat of the Integrated Growth Poles Project in February 2005.

Vincelette, M., Théberge, M. and Randrihasipara, L. 2007. Evaluations of forest cover at regional and local levels in the Tolagnaro Region since 1950. In: Biodiversity, Ecology and Conservation of Littoral Ecosystems In Southeastern Madagascar, Tolagnaro (Fort Dauphin). J. U. Ganzhorn, S. M. Goodman and M. Vincelette (eds.), pp 49-58. Smithsonian Institution, Washington D.C.

Virah-Sawmy, M. 2009. Ecosystem management in Madagascar during global change. Conservation Letters 2, 4: 163-170. (doi:10.1111/ j.1755-263X.2009.00066.X)

Watson, J. E. M., Joseph, L. N. and Fuller, R. A. 2010 Mining and conservation: Implications for Madagascar's littoral forests. Conservation Letters 3, 4: 286-287. (doi:10.1111/j.1755-263X.2010.00124.X)

White, B., Borras Jr., S.M., Hall, R., Scoones, I. and Wolford, W. 2012. The new enclosures: Critical perspectives on corporate land deals. Journal of Peasant Studies 39, 3-4: 619-647. (doi:10.1080/03066150.2012.6918 79)

World Bank 2005. Project Appraisal Document on a Proposed Credit in the Amount of SDR 85.9 million (US\$129.8 Million Equivalent) to the Republic of Madagascar for an Integrated Growth Pole Project. World Bank Report No: 31760-M, Private Sector Unit, Africa Region. Available at <http://siteresources.worldbank.org/EXTAFRSUMAFTPS/ Resources/Madagascar_PAD.pdf> 